\title{
PENDAMPINGAN KONSELOR SEBAYA UNTUK MENANGGULANGI PENGARUH LINGKUNGAN NEGATIF DI SMAN 10 KOTA JAMBI
}

\author{
Freddi Sarman, Asradi \\ Universitas Jambi \\ freddisarman@unja.ac.id
}

\begin{abstract}
Guidance and Counseling is an integral part of the educational process in schools. Its role and function is to prevent problems that interfere with the day-to-day effectiveness of students who are in the face of entering adolescence. Adolescence is also called the period of identity crisis, in this development process problems often arise. Complicating problems experienced by adolescents are not only the responsibility of parents, but also the responsibility of schools as formal education, a formal educational institution there is a student service that helps the problem called the Guidance and Counseling service. Therefore, through this community service, assistance is provided to students of SMAN 10 Jambi. This activity method uses a training and guidance model to monitor peer group counselors formed in schools. The results of this activity indicate that the formation of peer counselors is expected to be able to overcome the problems of students related to learning and student association. The formation of peer counselors can also minimize negative behavior among students.
\end{abstract}

Keywords: Assistance, Peer Counselors

\begin{abstract}
Abstrak
Bimbingan dn Konseling merupakan bagian integral pada proses pendidikan di sekolah. Peran dan fungsinya yaitu untuk mencengah terjadinya permasalahan yang mengganggu kefektifan seharihari siswa yag dalam face ini memasuki masa remaja. Masa remaja disebut juga dengan masa krisis identitas, dalam proses perkembangan ini sering muncul permasalahan. Permasalahan komplik yang dialami oleh remaja ini tidak hanya menjadi tanggung jawab orangtua, tetapi juga menjadi tanggung jawab sekolah sebagai pendidikan formal, suatu lembaga pendidikan formal terdapat suatu pelayanan siswa yang membantu permasalahan disebut dengan pelayanan Bimbingan dan Konseling (BK). Oleh karena itu melalui kegiatan pengabdian masyarakat ini dilakukan pendampingan kepada siswa SMAN 10 Kota Jambi. Metode kegiatan ini menggunakan model pelatihan dan bimbingan untuk memantau kelompok konselor sebaya yang dibentuk di sekolah. Hasil kegiatan ini menunjukkan bahwa pembentukan konselor sebaya ini diharapkan mampu menangai permasalahan siswa berkaitan dengan pelajaran maupun pergaulan siswa. Pembentukan konselor sebaya juga dapat meminimalisir perilaku negatif dikalangan siswa.
\end{abstract}

Kata Kunci: Pendampingan, Konselor Sebaya

\section{Pendahuluan}

Perkembangan zaman sekarang ini yang semakin modern memberikan dampak perubahan bagi perkembangan. Individu remaja terlihat lebih cepat dalam proses perkembangannya baik itu dari segi kedewasaan, hal itu disebabkan oleh berbagai macam faktor baik itu dari segi makanan yang semakin lengkap dan bergizi ataupun dari segi teknologi informasi yang sangat mudah didapat.

Perkembangan teknologi yang semakin pesat ini membawa dampak positif bagi perkembangan remaja, diantaranya remaja dengan senantiasa dapat menambah wawasan apapun untuk kepentingan pendidikannya maupun kehidupannya, tetapi perkembangan teknologi itu tidak mampu menghilangkan permasalahan permasalahan yang dihadapi remaja, bahkan permasalahan itu semakin berkembang atau meningkat. 
Perilaku perilaku agresif, perilaku seks bebas dan bahkan perilaku kriminal yang dilakukan oleh remaja dapat ditemui diseluruh daerah, baik itu kota-kota besar maupun daerahdaerah. Perilaku perilaku tersebut tentu tidak lepas dari pengaruh teknologi tersebut. Menurut Hasanah (2016) yang paling menonjol dari dampak negatif internet adalah adanya perubahan perilaku remaja yang cenderung tidak patuh pada orang tua, egois, individualis, kurang santun, dan melalaikan ibadah serta kurang kepedulian kepada keluarga.

Permasalahan komplik yang dialami oleh remaja ini tidak hanya menjadi tanggung jawab orangtua, tetapi juga menjadi tanggung jawab sekolah sebagai pendidikan formal. Pada lembaga pendidikan formal terdapat suatu pelayanan siswa yang diampu oleh para guru Bimbingan dan Konseling yang disebut dengan pelayanan BK, pelayanan ini berfungsi sebagai tempat atau wadah dalam pemberian bantuan kepada siswa dalam mengatasi kehidupan sehari-hari mereka yang terganggu atau disingkat dengan KES-T.

Namun demikian berdasarkan sedikit sekali siswa yang menggunakan jasa pelayanan konseling. Pelayanan BK dianggap siswa sebagai tempat untuk mengadili siswa-siswa yang bermasalah atau dalam pandangan mereka adalah tempat individuindividu yang tidak bisa diatur, sehingga banyak siswa yang menghindari yang berkaitan dengan bimbingan dan konseling, seperti hasil penelitian yang dilakukan oleh Sari (2010) menemukan bahwa siswa memiliki persepsi yang negatif terhadap guru BK. senada dengan yang ditemukan oleh Mardiana dkk (2012) persepsi dan sikap siswa terhadap layanan BK kurang menggembirakan.

Melihat permasalahan tersebut perlunya suatu metode baru dalam memaksimalkan pelayanan bimbingan dan konseling di sekolah, perlu suatu strategi pembaharuan dalam pelayanan untuk membantu siswa dalam memecahkan masalahnya dengan membentuk konselor sebaya. Hal ini diperkuat dengan tugas perkembangan remaja, dimana remaja membutuhkan pengakuan dari kelompok atau teman sebanyanya untuk meningkatkan kepercayaan diri (Hurlock, 2002)

\section{Metode}

Metode yang digunakan dalam pelaksanaan kegiatan pengabdian ini adalah pelatihan dan pendampingan, Melalui kegiatan ini peserta akan dilatih dan dibimbing serta diberikan pengetahuan tentang bimbingan dan konseling. Kegiatan pelatihan dan pendampingan akan menggunakan beberapa metode, sebagai berikut:

1. Ceramah/pemberian informasi

Pada tahap ini akan diberikan pemahaman tentang konselor sebaya (apa mengapa dan bagaimana konselor sebaya itu). Kegiatan ini dimaksudkan supaya siswa memiliki pemahaman yang berkaitan dengan konselor sebaya, hal ini nanti yang akan memudahkan untuk masuk ketahap pelatihan

2. Role Play

Tahap ini setelah pemahaman materi peserta akan mencobakan memerakan sebagai konselor sebaya, klien sebaya dan sebagai pengamat bergantian dengan mempraktekkan apa yang sudah dipahamai pada tahap sebelumnya. Pada tahap ini 
siswa diharapkan dapat menghayati peran tertentu mencoba dan merasakan menjadi seseorang tertentu dalam memahami proses sehingga memiliki gambaran aplikasinya

3. Simulasi dan Latihan

Pada tahap ini siswa mencobakan menghadapi permasalahan yang nyata dengan menjadi konselor dan salah seorangnya menjadi klien

4. Refleksi

Kegiatan ini merupakan bagian dari evaluasi kegiatan dengan tujuan melihat pemahaman peserta/siswa

5. Pendampingan Kelompok

Melalui pendampingan ini diharapkan hasil kegiatan ini dapat ditindak lanjuti dan dapat dilaksanakan berdasarkan pengalaman yang muncul selama pendampingan.

\section{Hasil dan Pembahasan}

Kegiatan pemdampingan konselor sebaya ini telah berjalan sesuai dengan rencana yang telah ditetapkan sebelumnya. Tahap-tahap pelaksanaan kegiatan sebagaimana berikut ini:

Persiapan, Pada tahap ini membutuhkan persiapan dengan waktu yang cukup lama, adapun persiapannya yaitu: a) penetapan sekolah mitra (lokasi kegiatan) dan peserta pelaksanaan kegiatan, pada tahap ini dimulai dengan penetapan waktu pelaksanaan yang disesuaikan dengan jadwal di sekolah, kemudian memasukkan surat ke sekolah terlebih dahulu. Setelah mendapatkan persetujuan langkah selanjutnya adalah menentukan peserta yang akan mengikuti kegiatan, peserta diambil dua orang tiap-tiap kelas mulai dari kelas X dan kelas XI, b) sosialisasi kegiatan kepada sekolah mitra, pada tahap ini dibahas schedule/susunan kegiatan yang akan dilakukan dan hal-hal yang perlu dipersiapkan untuk kelancaran kegiatan tersebut, c) melakukan koordinasi dengan tim, pada tahap ini merupakan tahap persiapan untuk pelaksanaan kegaitan, koordinasi denga tim (mahasiswa) dilaksanaan untuk mengkoordinasi tugas selama kegiatan, tim kegiatan ini adalah mahasiswa sebanyak dua orang. Dipersiapkan untuk membantu kelancaran kegiatan termasuk juga dalam pendampingan peserta kegiatan konseling teman sebaya d) mempersipkan materi kegiatan yang akan diberikan kepada seluruh peserta kegiatan dan mitra kegiatan.

Pelaksanaan, Pada tahap pelaksanaan kegiatan pengabdian pada masyarakat ini ada beberapa tahapan kegiatan yaitu:

a) Ceramah/ Pemberian Informasi

Luaran dari kegiatan ini adalah penanaman konsep konselor sebaya kepada peserta kegiatan sehingga menjadi bekal bagi calon konselor sebaya untuk dijadikan sebagai konselor sebaya di sekolah. Kegiatan pemberian informasi ini diikuti sebanyak 17 orang siswa yang berlangsung 3 jam untuk pendalaman teori .

Kegiatan ini berupa pemberian keahlian dasar konseling teman sebaya kepada peserta kegiatan. Tujuan dari tahap kegiaan ini adalah supaya peserta kegiatan memiliki pemahaman tentang konseling sebaya, proses konseling sebaya dan hal-hal yang mesti dimiliki oleh seorang konselor serta membentuk dasar keahlian konseling teman sebaya dan meningkatkan empati peserta. 
b) Role Play

Kegiatan ini bertujuan untuk menempatkan peserta pada tiga posisi tertentu secara bergantian (konselor sebaya, klien sebaya dan pengamat) peserta akan bermain peran masing-masing secara bergantian dengan memprakekkan teknik yang diperlukan dalam konseling. peserta membentuk kelompok sebanyak 3 orang dan mencobakan suatu teknik dengan problem yang diangkat sudah dicantumkan didalam materi. Kegiatan ini akan berlangsung selama 1 jam.

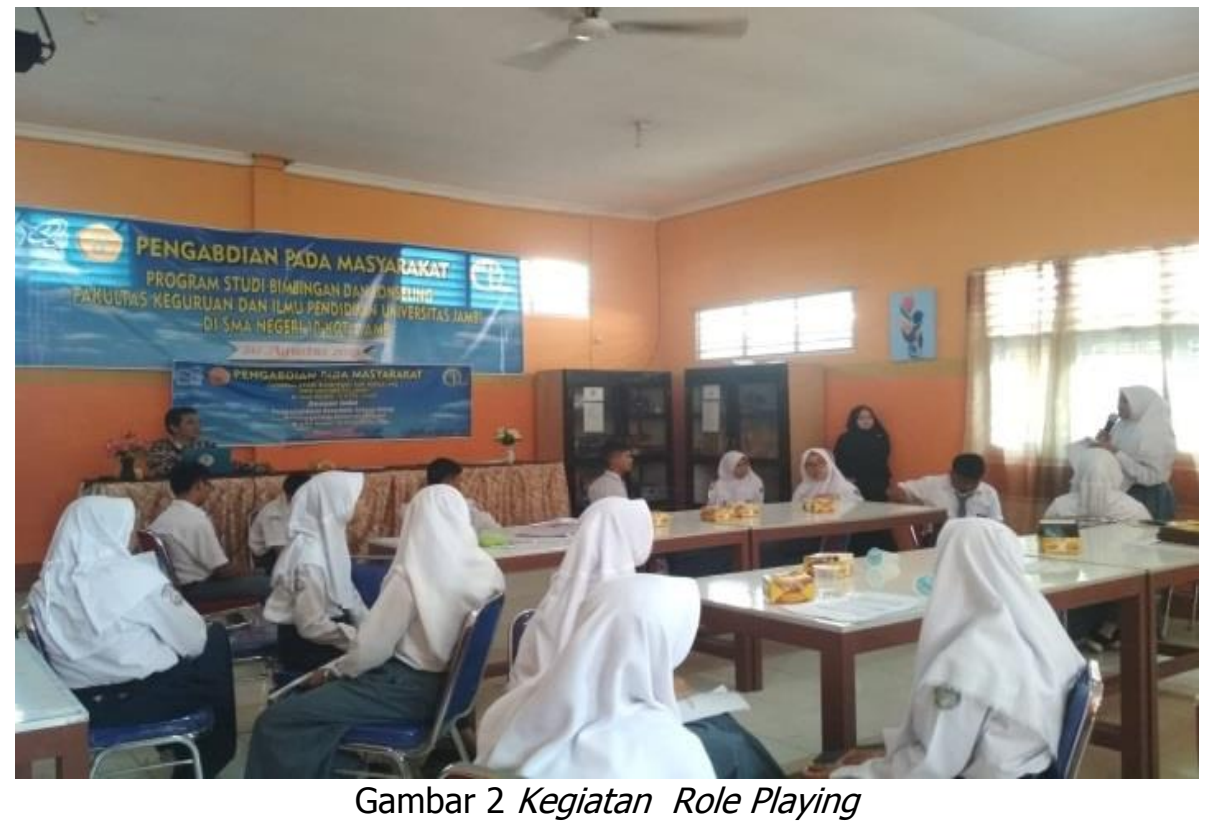

c) Simulasi dan latihan

Pada tahap ini peserta langsung mencobakan menempatkan diri sebagai seorang konselor sebaya dan salah satu menjadi seorang klien secara bergantian. Di tahap awal peserta akan diberikan rangkaian masalah yang akan dibahas, pada tahap berikutnya peserta kegiatan akan mengungkapkan permasalahan sendiri yang dimiliki.

Dengan tujuan agar peserta merasakan dengan langsung dan dapat melatih keterampilan konseling sebaya bagi caloan-calon konselor sebaya tersebut. Kegiatan ini akan berlangsung selama 3 jam kegiatan.

Pada tahap ini sesuai dengan capaian yang ingin dihasilkan yaitu meningkatkan kompetensi dan keahlian peserta dalam kegiatan konseling sebaya serta membentuk jiwa konselor sebaya. Pelatihan dibutuhkan untuk menemukan permasalahan yang dijumpai dalam kegiatan konseling teman sebaya. Kegiaan ini diharapkan dapat mempertajan keahlian dalam melakukan konseling sebaya agar dapat dipraktekkan nantinya dengan baik sesuai dengan norma yang ada. Maka dari itu kegiatan ini banyak dilakukan role playing dan simulasi kegiatan konseling dengan tujuan agar peserta dapat mengasah keahlian dengan berbagai masalah yang muncul.

d) Refleksi

Kegiatan ini bertujuan utuk melihat tingkat pemahaman peserta kegiatan dan keahlian yang didapatkan peserta kegiatan, berdasarkan hasil refleksi menunjukkan peserta sudah memahami dasar konsep konsor sebanya, kegiatan penyampaian 
materi untuk lebih dalam lagi diberikan karena peserta belum memiliki pemahaman dasra mengenai konseling.

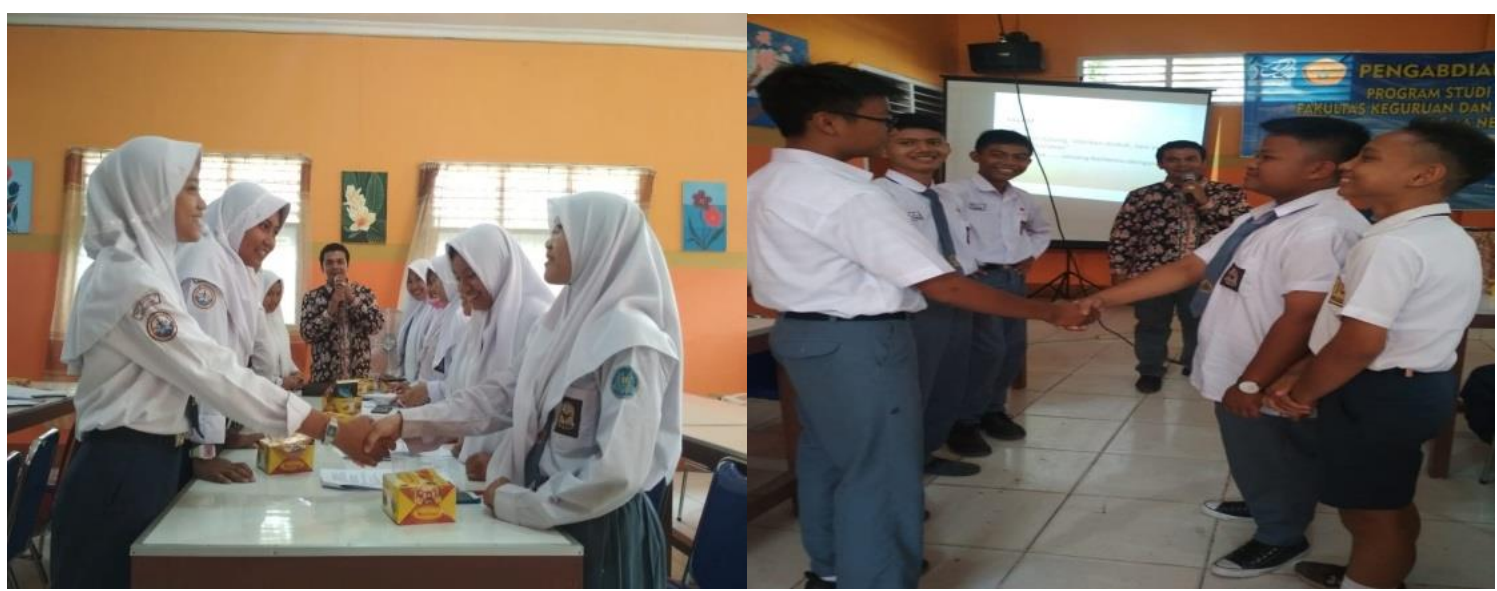

Gambar 3 Pelatihan Keterampilan Konseling

e) Pendampingan

Program pendampingan merupakan program kegiatan untuk memasatkan peserta melakukan kegiatan konseling dan memiliki kemapuan dasar yang dibutuhkan dlam melakukan konseling teman sabaya. Kegiantan ini juga menjembatani informasi terbaru berkaitan dengan permasalahan yang dihadapi oleh teman-teman sebayanya dan mermasalaan peserta dalam melakukan kegiatan, sehingga tim dapat menyususn langkah-langkah baru untuk membantu penyelesaian masalah pserta tersebut. Program pendampingan bertujuan untuk memberikan penguatan dari dalam diri peserta agar dapat dengan mandiri, terampil dan percaya diri melakuan kegiatan konseling. program pendampingan juga digunakan untuk melakukan sharing terhadap permasalahan yang dihadapi klien dan perserta yang menjadi konselor sebaya selama melakukan kegiatan konseling teman sebaya. Pemdampingan dilakukan selama 2 hari sesuai dengan kesepakatan mitra untuk memberikan pendampingan terhadap kegiatan konseling dilokasi masing-masing. Kegiatan ini sebagai suatu bentuk kerjasama berkesinambungan antara konselor, tim pengabdian dan pihak kampus. Kegiatan ini juga sebagai tindakan preventif terhadap perilaku negatif yang muncul dalam diri siswa dan lingkungan sekolah.

Kegiatan pendampingan ini secara tidak langsung membawa dampak positif kepada nuansa konselor di sekolah dan peningkatan kinerja guru bimbingan dan konseling di sekolah. Melalui kegiatan tersebut siswa baik kelompok maupun perorangan mendapatkan wawasan, pengetahuan dan keterampilan terkait dengan konselor sebaya. Berdasarkan observasi dan pengamatan dilingkungan dan aspek psikologis siswa, banyak hal yang harus dibantu oleh seorang guru BK untuk menyelesaikannya, maka dari itu konselor sebaya sebagai salah satu unsur yang dapat membnatu pelaksanaan BK di sekolah. Oleh karena itu peran serta siswa dalam pelaksanan materi dan keterampilan yang telah dilatih sangat di perlukan untuk mengembangkan pelayanan BK kepada siswa. 


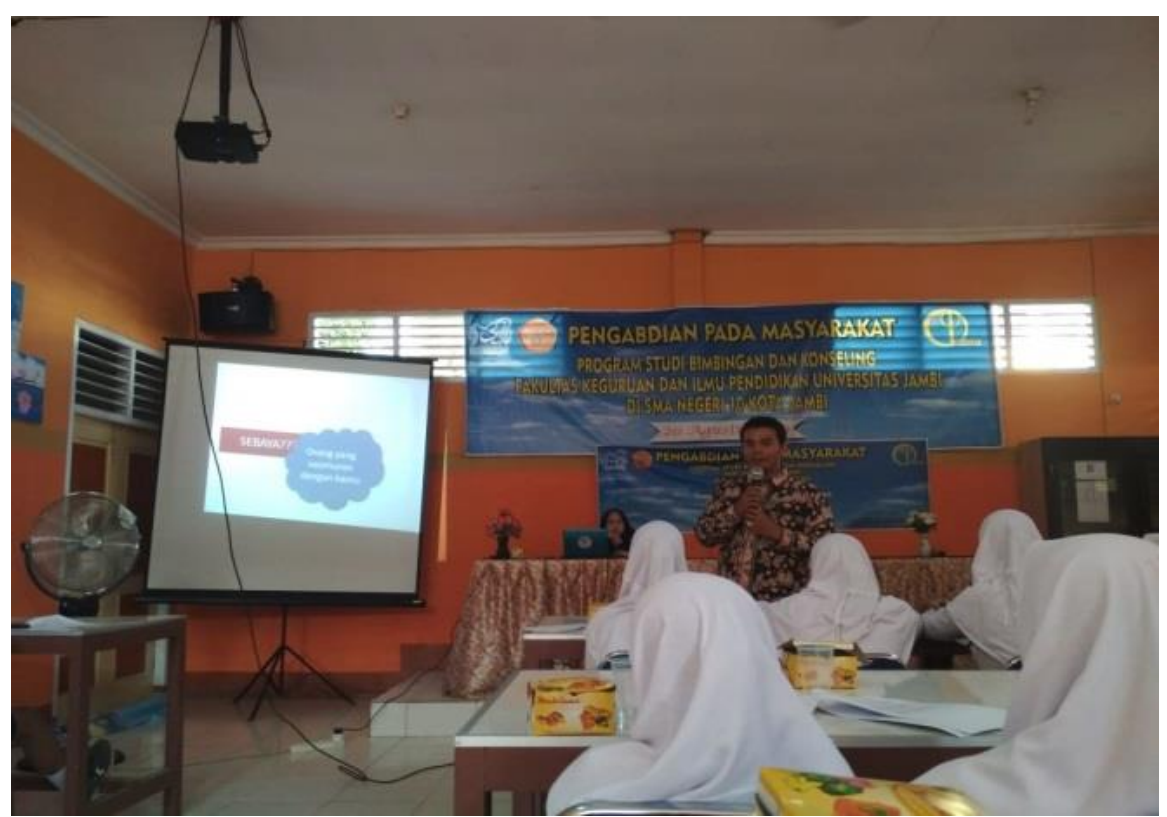

Gambar 1. Kegiatan Penyampaian Informasi Mengenai Konselor Sebaya

Berdasarkan evaluasi kegiatan pengabdian ada beberapa factor pendukung dan penghambar dalam pelaksanaan program ini. Secara garis besar akan dijabarkan sebagaimana berikut ini:

Factor pendukung a) tersedia tenaga ahli dalam penembangan modul b) antusiasme penerimaan sekolah dan dukungan kepala sekolah cukup tinggi c) ketersediaan dana pendukung dari fakultas guna penyelenggaraan pelaksanaan kegiatan.

Faktor penghambat: a) peserta masih banyak yang belum memiliki pengetahuan dasar konseling b) keterbatasan waktu c) membutuhkan waktu yang lebih banyak lagi untuk pemahaman secara mendalam terhadap siswa.

Secara garis besar ketercapaian kegiatan bias dilihat dari jumlah peserta yang ikut kegiatan sebanyak mancapai target yang dinginkan yaitu mewakili masing-masing kelas, ketercapaian tujuan kegiatan, ketercapaian materi yang diberikan, dan keterampilan siswa setelah mengikuti kegiatan.

Kegiatan pelatihan ini direncanakan sebelumnya adalah perwakilan masing-masing kelas dari kelas $X$ dan XI yang ada di SMAN 10 kota Jambi, kegiatan ini diikuti oleh 17 perserta siswa mewakili masing-masing kelas. Hal ini menunjukkan bahwa kegiatan ini dinyatakan berhasil.

Ketercapaiam pelaksanaan pendampingan secara umum sudah baik ,ditinjau dari keterampilan siswa dalam melaksanakan konseling sebaya yang sudah sesuai dengan tahap pelaksanaan dan teknik-teknik yang telah dilatihkan.

Ketercapaian target materi kegitan sudah berjalan sepenuhnyakarna materi sudah disampaikan secara keseluruhan. Materi yang disampaikan antara lain: a)pemahaman tentang konselor sebaya b) keterampilan yang harus dimiliki konselor sebaya $\mathrm{c}$ ) bermain peran (role playing). 


\section{Kesimpulan}

Berdasarkan pelaksanaan kegiatan pengabdian pada masyarakat dan evaluasi dengan mitra dapat disimpulkan bahwa: (a) Pelaksanaan kegiatan ini dapat membantu pelaksanaan bimbingan dan konseling di sekolah dengan adanya konselor teman sebaya. (b)Suatu bentuk penghargaan terhadap siswa yang telah aktif menggunakan pelayanan konseling di sekolah (c) Dapat mengantisipasi munculnya perilaku negatif di sekolah Keterampilan dan pengetahuan siswa berkembang sehinga dapat membantu pelaksanaan kegiatan bimbingan dan konseling di sekolah. Saran dari kegiatan ini adalah program pengabdian masyarakat perlu disempurnakan agar sesuai dengan rencana dan time line schedule dan memiliki pengembangan kegiatan yang luas.

\section{Daftar Pustaka}

Aryani, F. 2013. Program Konselor Sebaya. Makassar: UNM.

Hasanah, Uswatun. 2016. Dampak Kemajuan Teknologi Informasi dan Komunikasi terhadap Generasi Muda dalam Konteks Ketahanan Sosial Budaya. Universitas Gajah Mada.

Hurlock, E.B. 2002. Psikologi Perkembangan, terj. Istiwidiyanti dan Soedjarwo. Jakarta: Erlangga.

Mardiana, Annisa Rizka. 2012. Studi Tentang Persepsi Siswa Pada Layanan Bimbingan dan Konseling di SMK Se-Kecamatan Sukomanunggal Surabaya. Jurnal BK UNESA Volume 3 Nomer 1,72-8072.

Sari, Tri Retno. 2010. Persepsi Siswa Terhadap Guru Bimbingan Konseling di Sekolah Madrasah Aliayah Negeri Sidoarjo. Undergraduate thesis, IAIN Sunan Ampel Surabaya.

Tindall, J.D. and Gray, H.D. (1985). Peer Counseling: In-Depth Look At Training Peer Helpers. Muncie : Accelerated Development Inc. 